\title{
Pengaruh Hedonic Shopping Motivation, Shopping Lifestyle Dan Visual Merchandising Terhadap Impulse Buying (Pada Produk Fashion Mahasiswa Universitas Muhammadiyah Purwokerto)
}

\author{
Agnes Hidiani ${ }^{(1)}$ \\ Program Studi Manajemen S1 \\ Fakultas Ekonomi dan Bisnis Universitas Muhammadiyah Purwokerto ${ }^{(1)}$ \\ Email : ${ }^{1}$ gnneshidiani29@gmail.com \\ Tri Septin Muji Rahayu ${ }^{(2)}$ \\ Program Studi Manajemen S1 \\ Fakultas Ekonomi dan Bisnis Universitas Muhammadiyah Purwokerto ${ }^{(2)}$ \\ Email : ${ }^{2}$ septinharyanto@gmail.com
}

\begin{abstract}
ABSTRAK
Penelitian ini bertujuan untuk mengetahui pengaruh Hedonic Shopping Motivation, Shopping Lifestyle dan Visual Merchandising Terhadap Impulse Buying. Penelitian ini menggunakan metode kuantitatif. Populasi dalam penelitian ini adalah Mahasiswa Universitas Muhammadiyah Purwokerto.Teknik pengambilan sampel menggunakan purposive sampling. Sampel pada penelitian ini adalah sebesar 110 responden. Alat analisis yang digunakan dalam penelitian ini adalah regresi berganda. Hasil dari penelitian ini menunjukkan bahwa variabel Hedonic Shopping Motivation, Shopping Lifestyle, dan Visual Merchandising secara parsial dan simultan berpengaruh positif dan signifikan terhadap Impulse Buying.

Kata kunci : Hedonic Shopping Motivation, Shopping Lifestyle, Visual Merchandising, Impulse Buying.
\end{abstract}

\begin{abstract}
This study purposed to determine the effect of Hedonic Shopping Motivation, Shopping Lifestyle, and Visual Merchandising on Impulse buying. This research uses quantitative methods. The population in this study was college students at Universitas Muhammadiyah Purwokerto. The sample in this study was 110 respondents. The analytical tools used in this study are the multiple regression analysis. The results of this study indicate that variables Hedonic Shopping Motivation, Shopping Lifestyle, and Visual Merchandising partially and simultaneously have a positive and significant effect on Impulse buying.

Keywords: Hedonic Shopping Motivation, Shopping Lifestyle, Visual Merchandising, Impulse Buying.
\end{abstract}

\section{PENDAHULUAN}

\section{Latar Belakang}

Perkembangan dunia fashion yang semakin meningkat diiringi dengan perkembangan banyaknya pusat perbelanjaan seperti mall, butik, departement store, dan didukung dengan perkembangan internet yang memancing minat beli konsumen, memudahkan para konsumen untuk melakukan pembelian (Deviana, 2016) . Menurut penelitian yang dilakukan oleh Erlina dkk (2015) mendefinisikan fashion berasal dari bahasa Inggris yang berarti mode, gaya, cara dan kebiasaan. Saat ini fashion lebih mengarah pada suatu mode yang dipakai oleh individu atau kelompok seperti busana dan perhiasan, sekarang fashion tidak hanya sekedar berfungsi untuk memenuhi kebutuhan sehari-hari, tetapi 
sudah menjadi salah satu gaya hidup masyarakat. Fashion yang dipilih oleh seseorang menunjukkan bagaimana orang tersebut memilih gaya hidup yang dilakukannya.

Fashion merupakan suatu tujuan utama bagi para konsumen untuk melakukan kegiatan pembelian. Dampak dari adanya perkembangan fashion membuat konsumen mau tidak mau harus mengikuti trend yang ada saat ini. Kebutuhan fashion saat ini sudah menjadi kebutuhan pokok yang menjadikan konsumen sering kali melakukan pembelian yang melebihi rencana pembelian sebelumnya. Kegiatan tersebut menunjukkan bahwa konsumen sering melakukan pembelian yang tidak terencana yang dikenal dengan impulse buying (Ikanubun dkk, 2019 ). Melalui survey yang dilakukan terhadap 20 mahasiswa di Universitas Muhammadiyah Purwokerto yang melakukan pembelian produk fashion diperoleh hasil bahwa keseluruhan mahasiswa tersebut pernah melakukan impulse buying pada saat berbelanja produk fashion.

Impulse buying didefinisikan sebagai pembelian yang tidak direncanakan (Khuong dan Tran, 2015). Impulse buying merupakan pembelian saat itu juga yang tidak direncanakan sebelumnya dan didasarkan pada tindakan yang sangat kuat serta dorongan atau motivasi yang sangat kuat untuk membeli (Cahyono dkk, 2016). Faktor yang mempengaruhi impulse buying salah satunya adalah kegemaran berbelanja konsumen dengan melihat secara langsung bentuk dan tampilan yang tertera di dalam toko atau di gambar yang membuat konsumen tertarik untuk melakukan pembelian tanpa harus merencanakan terlebih dahulu. Pembelian produk yang mengikuti jaman hingga sesuatu yang ditemukan secara tidak sengaja, dan pembelian yang tidak direncankan meyebabkan terjadinya impulse buying (Deviana dan Giantri, 2016).

Faktor pertama yang mempengaruhi impulse buying yaitu hedonic shopping motivation. Dalam berbelanja, konsumen tidak hanya tertarik pada kualitas produk yang dijual di toko saja akan tetapi, konsumen berbelanja hanya berdasarkan kesenangan tanpa memikirkan manfaat dari produk yang dibelinya. Inilah yang disebut dengan hedonic shopping motivation, yakni motivasi berbelanja yang mengarah pada kesenangan (Purnomo dan Riani, 2018). Menurut penelitian yang dilakukan Hursepuny dan Oktafani (2018), Andryansyah dan Arifin (2018), Rahma dan Setrizola (2019) menunjukkan bahwa hedonic shopping motivation berpengaruh secara positif dan signifikan terhadap impulse buying.

Faktor kedua yang mempengaruhi impulse buying yaitu shopping lifestyle. Menurut Chaney (1996) dalam Andryansyah dan Arifin (2018) kebutuhan konsumen berpengaruh pada gaya hidup atau lifestyle. Gaya hidup seseorang untuk membelanjakan uang menjadikan sebuah status sosial dan karakteristik seorang individu. Banyaknya akan kebutuhan barang primer dan sekunder menjadikan konsumen selalu ingin memenuhi kebutuhan dan keinginannya, hal inilah yang mendasari terjadinya shopping lifestyle. Hasil penelitian terdahulu menurut Febriani dan Purwanto (2019), Deviana dan Giantri (2016) menunjukkan bahwa shopping lifestyle terbukti memiliki pengaruh positif dan signifikan terhadap impulse buying.

Faktor ketiga yang mempengaruhi impulse buying yaitu visual merchandising. Visual merchandising, atau presentasi visual, adalah sarana untuk mengkomunikasikan nilai fashion dan kualitas toko atau perusahaan kepada calon pelanggan (Thomas dkk, 2018). Konsumen menganggap bahwa tampilan toko dan Penyusunan produk yang menarik adalah salah satu daya tarik tersendiri bagi para konsumen untuk melakukan pembelian secara impulse buying. Menurut penelitian yang dilakukan oleh Wiguna dan Wijayanti, (2019), Muthiah dkk, (2018) mengatakan bahwa visual merchandising berpengaruh positif terhadap impulse buying. Sedangkan menurut penelitian yang dilakukan oleh Kertiana dan Artini (2019) menyatakan bahwa visual merchandising berpengaruh negatif dan tidak signifikan terhadap impulse buying. 
Penelitian ini merupakan penelitian pengembangan dari penelitian yang dilakukan oleh Hursepuny dan Oktafani, (2018) dengan variabel hedonic shopping motivation (X1), shopping lifestyle (X2) dan impulse buying (Y) selanjutnya menambah variabel visual merchandising (X3) dari penelitian yang dilakukan oleh Wiguna dan Wijayanti (2019). Subjek dari penelitian ini adalah Mahasiswa Universitas Muhammadiyah Purwokerto yang melakukan impulse buying pada produk fashion. Penelitian ini bertujuan untuk mengetahui pengaruh hedonic shopping motivation, shopping lifestyle dan visuaal merchandising terhadap impulse buying. Berdasarkan latar belakang di atas maka judul penelitian ini adalah "Pengaruh Hedonic Shopping Motivation, Shopping Lifestyle, dan Visual Merchandising Terhadap Impulse Buying ( Pada Produk Fashion Mahasiswa Universitas Muhammadiyah Purwokerto)."

\section{Rumusan Masalah}

Berdasarkan pada latar belakang diatas dapat disimpulkan beberapa permasalahan penelitian sebagai berikut :

1. Apakah hedonic shopping motivation berpengaruh positif signifikan terhadap impulse buying?

2. Apakah shopping lifestyle berpengaruh positif signifikan terhadap impulse buying?

3. Apakah visual merchandising berpengaruh positif signifikan terhadap impulse buying?

4. Apakah hedonic shopping motivation, shopping lifestyle dan visual merchandising secara simultan berpengaruh signifikan terhadap impulse buying ?

\section{Tujuan Penelitian}

Adapun tujuan yang ingin dicapai dari penelitian ini adalah :

1. Untuk mengetahui hedonic shopping motivation berpengaruh positif signifikan terhadap impulse buying.

2. Untuk mengetahui shopping lifestyle berpengaruh positif signifikan terhadap impulse buying.

3. Untuk mengetahui visual merchandising berpengaruh positif signifikan terhadap impulse buying.

4. Untuk mengetahui hedonic shopping motivation, shopping lifestyle dan visual merchandising secara simultan berpengaruh signifikan terhadap impulse buying.

\section{TINJAUN PUSTAKA}

\section{Hedonic Shopping Motivation}

Teori hedonistis menyatakan bahwa segala perbuatan manusia, entah itu disadari ataupun tidak disadari, entah itu timbul dari kekuatan luar ataupun kekuatan dalam, pada dasarnya mempunyai tujuan yang satu, yaitu mencari hal-hal yang menyenangkan dan menghindari hal-hal yang menyakitkan (Utami, $2017: 49$ ).

\section{Shopping Lifestyle}

Menurut Mowen dan Minor (2002), menyatakan bahwa gaya hidup adalah menunjukkan bagaimana orang hidup, bagaimana membelanjakan uangnya dan bagaimana mengalokasikan waktu (Priansa, 2017 : 185).

\section{Visual Merchandising}

Visual merchandising adalah kegiatan non-personal, merupakan presentasi produk dalam lingkungan toko (Vinci, 2009 : 65). Visual merchandising atau presentasi visual, adalah sarana untuk mengkomunikasikan nilai fashion dan kualitas toko atau perusahaan kepada calon pelanggan (Thomas dkk, $2018: 47$ ). 


\section{Impulse Buying}

Menurut Utami (2017 : 50) perilaku pembelian yang tidak direncanakan merupakan perilaku pembelian yang dilakukan di dalam toko, dimana pembelian berbeda dari apa yang telah direncanakan oleh konsumen pada saat mereka masuk ke dalam toko. Pembelian tidak terencana adalah suatu tindakan pembelian yang dibuat tanpa direncanakan sebelumnya, atau keputusan pembelian dilakukan pada saat berada di dalam toko.

\section{KERANGKA PEMIKIRAN}

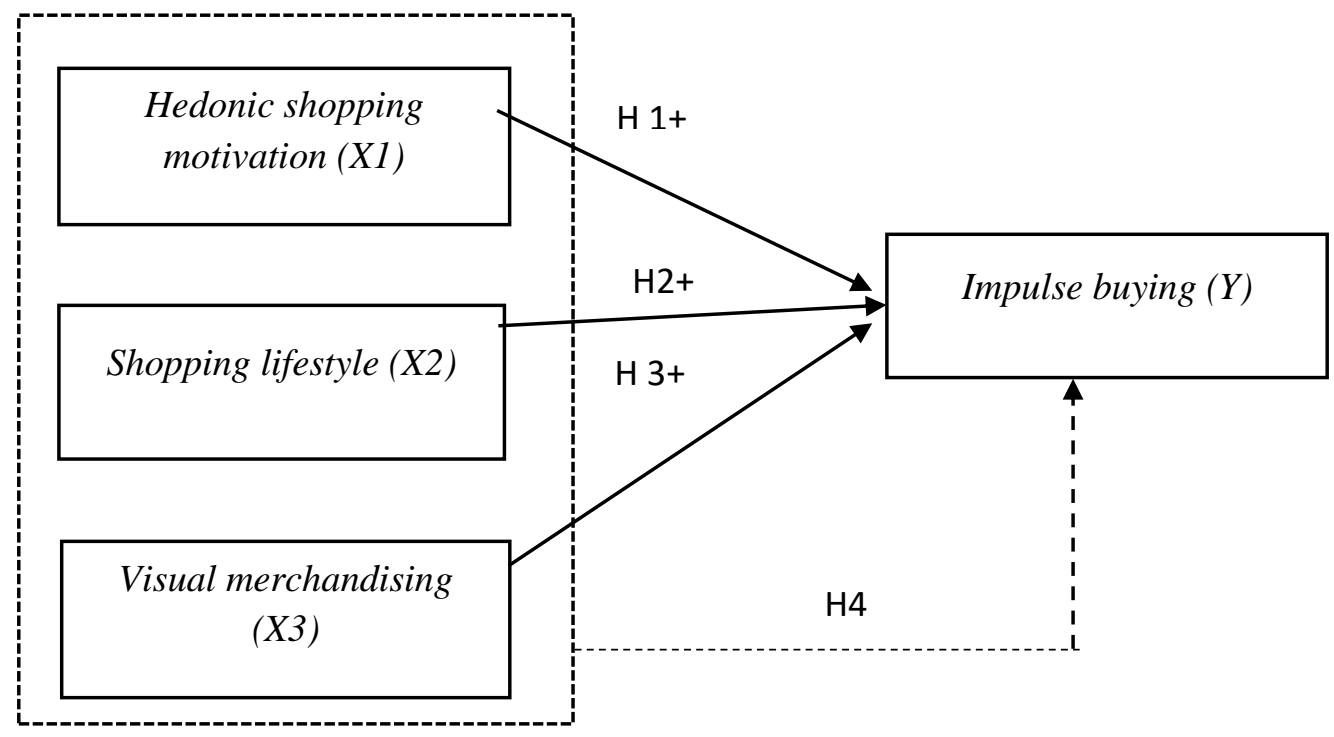

\section{METODE PENELITIAN}

Penelitian yang dilakukan ini menggunakan metode penelitian kuantitatif. Populasi dalam penelitian ini adalah Mahasiswa Universitas Muhammadiyah Purwokerto yang pernah melakukan pembelian produk fashion tanpa direncanakan. Jumlah sampel yang digunakan dalam penelitian sebanyak 110 responden. Teknik pengambilan sampel yang digunakan dalam penelitian ini adalah purposive sampling,dimana pengambilan sampel yaitu dengan pertimbangan tertentu menurut Sugiyono (2014 : 156). Data dalam penelitian ini merupakan data primer yang diperoleh dari penyebaran kuesioner. Teknik analisis data menggunakan analisis regresi berganda.

\section{HASIL DAN PEMBAHASAN \\ Uji Validitas dan Reliabilitas}

hasil perhitungan uji validitas dan reliabilitas menunjukkan bahwa seluruh pernyataan untuk variabel Hedonic Shopping Motivation, Shopping Lifestyle, Visual Merchandising, dan Impulse Buying adalah valid, karena memiliki nilai $\mathbf{r}_{\text {hitung }}$ (Corrected Item-Total Correlation) $>r_{\text {tebel }}$ sebesar 0,1576 atau tingkat signifikansi $<0,05$. Selanjutnya, hasil koefisien reliabilitas instrumen Hedonic Shopping Motivation diperoleh nilai Cronbach Alpha sebesar 0,688, instrumen Shopping Lifestyle sebesar 0,682, instrumen Visual Merchandising sebesar 0,776 dan instrumen Impulse Buying sebesar 0,832 , yang berarti keempat instrumen dinyatakan reliabel. 


\section{Uji Asumsi Klasik}

\section{a. Normalitas}

Dalam penelitian ini data tersebut berdistribusi normal.

\section{b. Multikolinearitas}

Variabel Hedonic Shopping Motivation, Shopping Lifestyle, dan Visual Merchandising mempunyai angka tolerance $>0,1$ dan mempunyai nilai VIF $<10$ maka dapat disimpulkan data ini bebas dari asumsi multikolinearitas.

\section{c. Heterokedastisitas}

Nilai signifikan variabel Hedonic Shopping Motivation sebesar 0,788, variabel Shopping Lifestyle sebesar 0,110 dan variabel Visual Merchandising sebesar 0,102. Dengan demikian, dapat diartikan bahwa model regresi terbebas dari gejala heterokedastisitas.

\section{Uji Regresi Linier Berganda}

$Y=-0,605+0,276 X_{1}+0,353 X_{2}+0,437 X_{3}$

\section{Uji Kecocokan Model}

\section{Uji Determinasi}

\section{Model Summary}

\begin{tabular}{|r|r|r|r|r|}
\hline Model & R & R Square & $\begin{array}{c}\text { Adjusted R } \\
\text { Square }\end{array}$ & $\begin{array}{c}\text { Std. Error of } \\
\text { the Estimate }\end{array}$ \\
\hline &, $587^{\mathrm{a}}$ &, 345 &, 326 &, 68892 \\
\hline
\end{tabular}

Dari tabel di atas dapat dilihat bahwa nilai adjusted $R$ square dari model regresi yang terbentuk dalam penelitian ini adalah sebesar 0,326 yang menunjukkan bahwa kemampuan variabel independen (hedonic shopping motivation, shopping lifestyle dan visual merchandising ) dalam menjelaskan variabel dependen (impulse buying) adalah sebesar $32,6 \%$ dan sisanya sebesar $67,4 \%$ dijelaskan oleh variabel lain yang tidak termasuk dalam model.

\section{Hipotesis}

a. Uji t

1. Hipotesis Pertama

Berdasarkan hasil dari pengujian diketahui bahwa variabel hedonic shopping motivation menunjukkan nilai $\mathrm{t}_{\text {hitung }} 2,178$ dan $\mathrm{t}_{\text {tabel }}$ sebesar 1,659. Nilai $\mathrm{t}_{\text {tabel }}$ didapat dari $n-k=110-4=106$ maka $t_{\text {tabel }}$ sebesar 1,659. Hal ini berarti $t_{\text {hitung }}>t_{\text {tabel }}(2,178>$ 1,659) dan nilai signifikannya $0,032<0,05$. Artinya Ho ditolak dan Ha diterima. Artinya hedonic shopping motivation berpengaruh positif signifikan terhadap impulse buying, dengan demikian hipotesis pertama dinyatakan diterima.

2. Hipotesis Kedua

Berdasarkan hasil dari pengujian diketahui bahwa variabel shopping lifestyle diperoleh nilai $\mathrm{t}_{\text {hitung }}$ sebesar 3,015 dan $\mathrm{t}_{\text {tabel }}$ sebesar 1,659. Nilai $\mathrm{t}_{\text {tabel }}$ didapat dari $\mathrm{n}-\mathrm{k}$ $=110-4=106$ maka $t_{\text {tabel }}$ sebesar 1,659. Hal ini berarti $t_{\text {hitung }}>t_{\text {tabel }}(3,015>1,659)$ dan nilai signifikannya $0,003<0,05$. Artinya Ho ditolak dan Ha diterima. Artinya shopping lifestyle berpengaruh positif signifikan terhadap impulse buying, dengan demikian hipotesis kedua dinyatakan diterima.

3. Hipotesis Ketiga 
Berdasarkan hasil dari pengujian diketahui bahwa variabel visual merchandising diperoleh nilai $\mathrm{t}_{\text {hitung }}$ sebesar 3,753 dan $\mathrm{t}_{\text {tabel }}$ sebesar 1,659. Nilai $\mathrm{t}_{\text {tabel }}$ didapat dari $\mathrm{n}-\mathrm{k}$ $=110-4=106$ maka $t_{\text {tabel }}$ sebesar 1,659 . Hal ini berarti $t_{\text {hitung }}>t_{\text {tabel }}(3,753>1,659)$ dan nilai signifikannya $0,000<0,05$. Artinya Ho ditolak dan Ha diterima. Artinya visual merchandising berpengaruh positif signifikan terhadap impulse buying, dengan demikian hipotesis ketiga dinyatakan diterima.

\section{b. Uji F}

\begin{tabular}{|l|c|c|c|c|c|}
\hline \multicolumn{1}{|c|}{ Model } & Sum of Squares & Df & Mean Square & F & Sig. \\
\hline Regression & 26,450 & 3 & 8,817 & 18,577 & $.000^{\mathrm{b}}$ \\
Residual & 50,309 & 106 &, 475 & & \\
Total & 76,760 & 109 & & & \\
\hline
\end{tabular}

Berdasarkan tabel di atas terlihat bahwa pengujian pengaruh variabel bebas secara bersama-sama terhadap variabel terikatnya dilakukan dengan menggunakan uji ANOVA. Hasil perhitungan statistik menunjukkan nilai $\mathrm{F}_{\text {hitung }}=18,577>\mathrm{F}_{\text {tabel }}=\mathrm{df} 1$ $=4-1=3$ dan df $2=110-4=106$. Maka didapat nilai $\mathrm{F}_{\text {tabel }}$ sebesar 2,69. Dari hasil tabel ANOVA didapat nilai $\mathrm{F}_{\text {hitung }}>\mathrm{F}_{\text {tabel }}(18,577>2,69)$ dan nilai signifikan sebesar $0,000<0,05$. Artinya secara simultan variabel hedonic shopping motivation, shopping lifestyle, dan visual merchandising berpengaruh terhadap impulse buying. Hal ini berarti hipotesis keempat diterima.

\section{Pembahasan}

\section{a. Pengaruh Hedonic Shopping Motivation Terhadap Impulse Buying}

Hasil penelitian hipotesis pertama menunjukkan bahwa ada pengaruh positif signifikan hedonic shopping motivation terhadap impulse buying pada produk fashion Mahasiswa Universitas Muhammadiyah Puwokerto. Hal ini dibuktikan karena nilai $t_{\text {hitung }}>t_{\text {tabel }}(2,178>1,659)$ dan nilai signifikannya $0,032<0,05$.

Artinya hedonic shopping motivation akan muncul ketika seseorang mengetahui adanya trend baru dan juga adanya penawaran khusus atau diskon yang membuat konsumen tertarik dan melakukan pembelian produk, meskipun tidak terlalu dibutuhkan. Hal ini yang menyebabkan motivasi belanja akan berpengaruh terhadap impulse buying.

Hasil penelitian ini didukung dengan penelitian yang dilakukan oleh Hursepuny dan Oktaviani (2018), Andryansyah dan Arifin (2018), Rahma dan Septrizola (2019) yang menyatakan bahwa hedonic shopping motivation berpengaruh positif dan signifikan terhadap impulse buying.

\section{b. Pengaruh Shopping Lifestyle Terhadap Impulse Buying}

Hasil penelitian hipotesis kedua menunjukkan bahwa ada pengaruh positif signifikan shopping lifestyle terhadap impulse buying pada produk fashion Mahasiswa Universitas Muhammadiyah Puwokerto. Hal ini dibuktikan karena nilai $t_{\text {hitung }}>t_{\text {tabel }}(3,015>1,659)$ dan nilai signifikannya $0,003<0,05$.

Artinya konsumen melakukan pembelian fashion karena adanya suatu perubahan gaya hidup, adanya tawaran iklan, dan karena adanya merek terkenal. Perubahan gaya hidup menjadi faktor utama penyebab terjadinya impulse buying. Hal ini dikarenakan dengan adanya produk fashion yang baru maka akan membuat konsumen tertarik dan membeli produk tersebut. 
Hasil penelitian ini didukung oleh hasil penelitian yang dilakukan oleh Febriani dan Purwanto (2019), Deviana dan Giantari (2016) yang menyatakan bahwa shopping lifestyle berpengaruh positif dan signifikan terhadap impulse buying.

c. Pengaruh Visual Merchandising Terhadap Impulse Buying

Hasil penelitian hipotesis ketiga menunjukkan bahwa ada pengaruh positif signifikan visual merchandising terhadap impulse buying pada produk fashion Mahasiswa Universitas Muhammadiyah Puwokerto. Hal ini dibuktikan karena nilai $t_{\text {hitung }}>t_{\text {tabel }}(3,753>1,659)$ dan nilai signifikannya $0,000<0,05$.

Artinya tampilan toko menjadi salah satu faktor yang paling penting dan paling berpengaruh terhadap ketertarikan konsumen untuk melakukan pembelian produk. Hal ini akan mempermudah konsumen memilih barang-barang yang sesuai dengan keinginannya dan juga dengan adanya nuansa seperti warna toko yang menarik dan produk yang beranekaragam ditambah dengan penataan peralatan yang rapih akan memberikan kenyamanan kepada konsumen. Hal ini menunjukkan bahwa visual ini dapat mendorong impulse buying.

Hasil penelitian ini didukung oleh hasil penelitian yang dilakukan oleh Wiguna dan Wijayanti (2019), Thomas dan Vipinkumar (2018) menyatakan bahwa visual merchandising berpengaruh positif dan signifikan terhadap impulse buying.

d. Pengaruh Hedonic Shopping Motivation, Shopping Lifestyle dan Visual Merchandising Terhadap Impulse Buying

Hasil penelitian hipotesis keempat menunjukkan bahwa ada pengaruh secara simultan hedonic shopping motivation, shopping lifestyle dan visual merchandising terhadap impulse buying pada produk fashion Mahasiswa Universitas Muhammadiyah Puwokerto. Hal ini dibuktikan karena nilai $F_{\text {hitug }}>F_{\text {tabel }}(18,577>$ $2,69)$ dan nilai signifikannya $0,000<0,05$. Artinya bahwa hipotesis keempat diterima.

\section{SIMPULAN DAN SARAN \\ Simpulan}

Berdasarkan hasil analisis data dan pembahasan hasil penelitian serta hasil pengujian data yang telah dilakukan maka dapat diambil sebagai suatu kesimpulan sebagai berikut :

a. Hedonic Shopping Motivation berpengaruh positif signifikan terhadap Impulse Buying.

b. Shopping Lifestyle berpengaruh positif signifikan terhadap Impulse Buying.

c. Visual Merchandising berpengaruh positif signifikan terhadap Impulse Buying.

d. Hedonic Shopping Motivation, Shopping Lifestyle dan Visual Merchandising secara simultan berpengaruh terhadap Impulse Buying.

Saran

Berdasarkan penelitian ini, peneliti menyadari masih terdapat banyak kekurangan di dalamnya. Saran dari peneliti ini adalah sebagai berikut :

1. Bagi Peneliti Selanjutnya

a. Diharapkan peneliti selanjutnya memperluas sampel penelitian sehingga diharapkan dapat menggeneralisasikan hasil penelitiannya.

b. Peneliti selanjutnya diharapkan menambah variabel bebas lainnya, karena dalam penelitian ini nilai adjusted $\mathrm{R}^{2}$ sebesar 0,326 artinya hedonic shopping motivation, shopping lifestyle, dan visual merchandising mempengaruhi impulse buying sebesar $32,6 \%$ yang artinya masih terdapat $67,4 \%$ variabel lain yang dapat mempengaruhi impulse buying. 
2. Bagi Perusahaan

a. Hedonic shopping motivation merupakan hal yang perlu diperhatikan oleh perusahaan. Perusahaan disarankan terus menciptakan mode atau tren baru dan juga memberikan penawaran khusus atau diskon terhadap produknya karena dengan adanya tren produk terbaru dan adanya diskon akan menumbuhkan motivasi belanja para konsumen, sehingga hal tersebut akan membuat konsumen melakukan impulse buying.

b. Shopping lifestyle adalah bagian yang tidak bisa dipisahkan oleh seseorang saat ini, karena gaya hidup sudah dianggap menjadi kebutuhan pokok bagi seseorang, sehingga perusahaan perlu membuat iklan yang lebih menarik mengenai produk yang dijual dan juga menjaga kualitas dari produk tersebut. Dengan adanya iklan yang menarik dan kualitas produk yang bagus, hal ini akan mempengaruhi konsumen melakukan impulse buying.

c. Visual merchandising merupakan hal yang perlu diperhatikan dan dipertahankan oleh perusahaan. Perusahaan disarankan selalu memperhatikan tampilan toko dan cara peletakan barang yang sesuai. Karena dengan adanya tampilan toko yang rapih dan menarik maka akan membuat konsumen tertarik untuk datang dan melakukan impulse buying. Jika perusahaan menjual produk fashion secara online maka perusahaan harus membuat website yang berisi informasi dan gambaran suatu produk yang akan dijual oleh perusahaa, karena hal ini akan membuat konsumen tertarik untuk melakukan impulse buying.

\section{DAFTAR PUSTAKA}

Andryansyah, M. dan Arifin, Z. 2018. Pengaruh Hedonic Motives Terhadap Shopping Lifestyle dan Impulse buying (Survei Pada konsumen Hypermart Malang Town Square Yang Melakukan Pembelian Tidak Terencana). Jurnal Administrasi Bisnis (JAB). Vol. 57. No. 1 April 2018.

Cahyono, K, E, Khuzaini dan Widiarto ,H. 2016. Shopping Lifestyle Memediasi Hubungan Hedonic dan Utilitarian Value Terhadap Impulse buying. Jurnal Ekonomi dan Keuangan. Vol. 20. No. 2. Juni 2016.

Darmaningrum, P.C.C. dan Sukaatmadja, I.P.G. 2019. Peran Shopping Enjoyment Memediasi Pengaruh Hedonic Motivation Terhadap Impulse buying. E-Jurnal Manajemen. Vol. 8. No. 6. 2019.

Febriani, S. F. dan Purwanto, N. 2019. Pengaruh Shopping Lifestyle dan Fashion Involvement Terhadap Impulse Buying Pada Konsumen Hijab Butik Rabani Jombang. Jurnal Riset Manajemen dan Bisnis Dewantara. Vol. 2. No. 2. Desember 2019.

Ghozali, Imam. 2016. Aplikasi Analisis Multivariete Dengan Program IBM SPSS21. Semarang : Badan Penerbit Universitas Diponegoro.

Hursepuny, C, V. dan Oktafani, F. 2018. Pengaruh Hedonic Shopping Motivation dan Shopping Lifestyle Terhadap Impulse buying Pada Konsumen Shoppe_Id. Jurnal e-proceeding of Management. Vol. 5. No. 1. Maret 2018.

Ikanubun, D. Setyawati, S.M. dan Afif, N.C. 2019. Pengaruh Hedonic Shopping Terhadap Impulse Buying Yang diMediasi Emosi Positif (Survei Pada Konsumen Toko Fashion di Kota "X"). Jurnal Ekonomi, Bisnis, dan Akuntansi (JEBA). Vol. 21. No.01. 2019.

Jovita, Guntara, Sudarsono. 2017. Pengaruh Visual Merchandising Terhadap Impulse buying Melalui Positive Emotion Pada Zara Surabaya. Jurnal Manajemen Pemasaran. Vol. 11. No. 1. April 2017. 
Kertiana, K. D. I. dan Artini .S. 2019. Pengaruh Visual Merchandising, Atmosfer Toko dan Display Produk Terhadap Impulse Buying Pelanggan Ramayana Denpasar. E-Jurnal Manajemen. Vol. 8. No. 11. 2019.

Khoung, M. N. dan Tran, T. B. 2015. Factors Affecting Impulse buying toward Fashion Product in Ho Chi Minh City A Mediation Analysis of Hedonic Purchase. International Journal of Trade, Economics and Finance. Vol. 6. No. 4. Agustus 2015.

Lia, Octaria, Pasaribu dkk. 2015. Pengaruh Hedonic Shopping Motivation Terhadap Impulse buying Pada Toko Online: Studi Pada Toko Online Zalora. Jurnal Administrasi Dan Bisnis. Vol. 19. No. 2. 2015.

Mangkunegara, A,P. 2012. Perilaku Konsumen. Bandung : PT Refika Aditama.

Muthiah, I., Parawansa, D.A.S. dan Munir, A.R. 2018. Pengaruh Visual Merchandising, Display Product, dan Store Atmosphere Terhadap Perilaku Impulse buying Studi Kasus Konsumen Matahari Department Store di Kota Makassar. HJABE. Vol. 1. No. 2. April 2018.

Nasreen Khan \& Hong Young Hoe. 2016. Impulse buying Behaviour of Generation Y in Fashion Retail. International Journal of Business and Management Publised Canadian of Science and Education. Vol. 11. No. 1. 2016.

Purnomo, H. dan Riani, L, P. 2018. Analisis Hedonic Shopping Motives Terhadap Impulse buying Toko Darling Pada Masyarakat Kota Kediri. Jurnal Bisnis Dan Manajemen. Vol. 2. No. 1. 2018.

Putri, A. S.K. dan Suharyono. 2017. Pengaruh Shopping Motives dan Promosi Penjualan Terhadap Impulse buying Survei Pada Konsumen Matahari Departement Store Malang Town Square). Jurnal Administrasi Bisnis (JAB). Vol. 47. No. 2 Juni 2017.

Priansa. 2017. Perilaku Konsumen Dalam Persaingan Bisnis Kontemporer. Bandung : ALFABETA

Rahma, W, S. dan Septrizola, W. 2019. Pengaruh Hedonic Shopping Motivation dan Shopping Lifestyle Terhadap E-Impulse Buying Mahasiswa Universitas Negeri Padang pada Lazada.co.id. Jurnal Kajian Manajemen dan Wirausaha. Vol. 01. No. 01. 2019.

Steven, W. Hartley, Roger A. Kerin. 2013. Marketing the Core. United State : MCGraw Hill

Sugiyono. 2014. Metodologi Penelitian Kuantitatif, Kualitatif dan $R \& D$. Bandung : ALFABETA.

Suliyanto. 2011. Teori dan Aplikasi Dengan SPSS. Yogyakarta : Andi

Suliyanto. 2018. Metode Penelitian Bisnis. Yogyakarta : Andi

Thomas, A. Louise. R., dan VP.V. 2018. The Impack Of Visual Merchandising, On Impulse buying Behaviour Of Retail Customers. International Journal For Research in Applied Scine \& Engineering Technology (IJRASET). Vol. 6 Issue 11, February 2018.

Utami, Christina Whidya. 2017. Manajemen Ritel. Jakarta : Salemba Empat.

Vinci, Maharani. 2009. Manajemen Bisnis Eceran. Bandung : Sinar Baru Algensido.

Wahyuni, D.F. dan Rachmawati. I. 2018. Hedonic Shopping Motivation Terhadap Impulse Buying Pada Konsumen Toko Pedia. Jurnal Riset Bisnis dan Manajemen. Vol. 11. No. 2 Agustus 2018.

Wiguna, P. dan Wijayanti, N.W. 2019. Pengaruh Word Of Mouth (WOM), Visual Merchandising dan Creative Promotion Terhadap Impulse Buying Minyak Kutus-Kutus di Denpasar. Jurnal Ilmiah Manajemen dan Bisnis. Vol. 4. No. 1 Juni 2019. 
